\title{
IDENTIFIKASI IRIS \\ OPSI IDENTIFIKASI BIOMETRIK
}

\author{
${ }^{1}$ Erwin G. Kristanto \\ ${ }^{1}$ Elisa Rompas \\ ${ }^{2}$ Sunny Wangko
}

\author{
${ }^{1}$ SMF Kedokteran Forensik \& Medikolegal RSUP Prof. Dr. R.D. Kandou Manado \\ ${ }^{2}$ Bagian Anatomi-Histologi Fakultas Kedokteran Universitas Sam Ratulangi Manado \\ Email: gk_erwin@yahoo.com
}

Perkembangan teknologi dalam kehidupan sehari-hari membuat timbulnya kebutuhan untuk membuktikan pada mesin dan sistem bahwa seorang individu ialah pemilik identitas yang ditampilkan oleh mesin dan sistem tersebut. Aktivitas membuka pintu, absensi, membuka komputer, hingga membuat dokumen, membutuhkan verifikasi bahwa kegiatan tersebut dilakukan oleh orang yang tepat. Kebutuhan ini dijawab dengan suatu metode identifikasi yang disebut identifikasi biometrik.

Penggunaan identifikasi biometrik membantu peningkatan keamanan sistem komputer dengan menggantikan penggunaan kata kunci (password) yang dapat diretas. Password yang terdiri dari 6 karakter tanpa karakter khusus walau memiliki 2,25 miliar kemungkinan kombinasi, ternyata dapat diretas dalam beberapa detik dengan menggunakan sebuah server komputer. Akun media sosial yang memiliki pengaman yang cukup baik, ternyata banyak yang diretas dan kemudian disalahgunakan.

Identifikasi iris dianggap merupakan salah satu metode identifikasi biometrik yang ideal dan lebih stabil karena iris adalah organ internal yang terproteksi oleh kornea. Beberapa kekurangan metode ini ialah pada pengguna kacamata, lensa kontak, atau cadar, serta peminum alkohol.

\section{STRUKTUR HISTOLOGIK IRIS}

Iris merupakan bagian berwarna bola mata, berbentuk donat gepeng yang terletak di antara kornea dan lensa, dan dilekatkan pada bagian luarnya ke prosesus siliaris. Stroma iris kaya akan vaskularisasi dan permukaan posteriornya dilapisi sel-sel yang kaya pigmen yaitu epitel pigmen posterior dengan lamina basalis yang menghadap ke ruang posterior mata. Ke arah anterior terdapat lapisan mio-epitel pigmen anterior; bagian apikal sel-sel ini mengandung pigmen. Bagian basal sel-sel mioepitel mempunyai tonjolan-tonjolan mengandung elemen kontraktil yang membentuk $m$. dilatator pupillae. Pada stroma iris dekat batas pupil terdapat sel-sel otot polos yang tersusun meling-kari pupil, yaitu $m$. constrictor pupillae. Permukaan anterior iris memperlihatkan tonjolantonjolan dan lekukan yang tersusun oleh lapisan yang tidak kontinu dari fibroblas dan melanosit (Gambar 1 A, B).

Iris berfungsi untuk mengatur jumlah cahaya yang masuk ke bagian posterior bola mata melalui pupil. Pada rangsangan cahaya terang, serat saraf parasimpatis merangsang otot polos sirkular ( $m$ constrictor pupillae) untuk berkontraksi dan menyempitkan ukuran pupil (konstriksi). Pada cahaya redup, serat saraf simpatis merangsang otot polos radial $(\mathrm{m}$. dilatator pupillae) untuk berkontraksi dan memperbesar ukuran pupil (dilatasi). Respons-respons ini bersifat refleks viseral. 

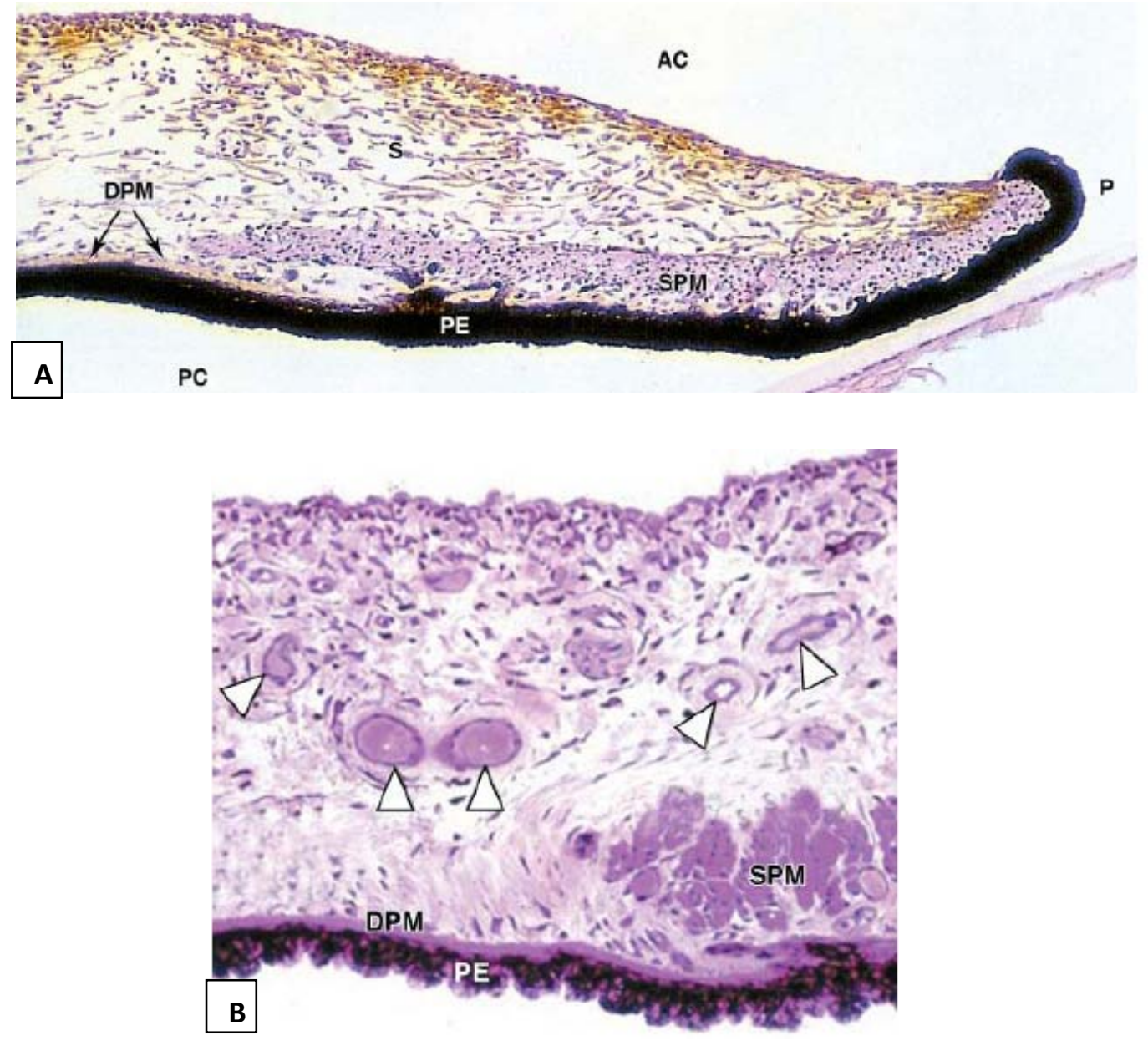

Gambar 1. A, Iris: potongan iris bagian tengah, dekat pupil. Permukaan anterior (berbatasan dengan akueus humor, AC) tidak mempunyai epitel dan terdiri dari lapisan fibroblas yang berinterdigitasi dan melanosit. Stroma di bawahnya (S) mengandung banyak melanosit dengan kandungan melanin yang bervariasi. B, Mikrograf memperlihatkan stroma bagian dalam yang kaya pembuluh darah (anak panah). Epitel iris bagian posterior terdiri dari dua lapisan sel kubis, yang sangat kaya dengan granula melanin untuk melindungi mata bagian dalam dari cahaya yang berlebihan. Ke arah anterior terdapat lapisan mioepitel (lebih kurang mengandung pigmen) yang menyusun $m$. dilatator pupillae (DPM), sedangkan di dekat pupil terdapat $m$. sphincter pupillae. Sumber: Mescher AL, 2010.

\section{IDENTIFIKASI BIOMETRIK}

Identifikasi biometrik adalah metode pengukuran objektif atas karakteristik fisik tertentu dari seseorang. Data biometrik dari sekelompok orang bila disimpan dalam sebuah bank data, dapat digunakan untuk verifikasi identitas orang dalam kelompok tersebut. Metode identifikasi biometrik yang telah banyak digunakan yaitu sidik jari, pengenalan wajah dan identifikasi iris. Negara tertentu seperti Amerika serikat, RRC, India, dan Indonesia, telah menerapkan penggunaan identifikasi biometrik dalam pembuatan identitas resmi warga negara maupun wisatawan yang akan masuk ke negaranya. Penggunaan metode identifikasi biometrik menghindarkan terjadinya salah identifikasi maupun pemalsuan identitas seseorang, dengan berbagai maksud. Identifikasi biometrik juga dapat membantu mengenali orang atau jenazah yang sebelumnya tidak diketahui identitasnya.

Mekanisme penggunaan sistem biometrik dapat digambarkan dengan beberapa fase. Fase pertama yaitu fase pemasukan data (enrollment). Pada fase ini 
masukan akan di pindai oleh sensor biometrik, yang mengambil data digital karakteristik anggota tubuh seseorang. Fase ini dilanjutkan dengan fase pencocokan; dalam fase ini sekelompok data pembanding yang telah dimasukkan sebelumnya akan dicocokkan dengan identifikasi data yang dimasukkan pada fase pertama.

Pada pencatatan data digital dimungkinkan adanya reduksi, sehingga dihasilkan data digital yang bebas dari data yang menyebabkan kesalahan identifikasi. Hasil ini akan diproses dengan ekstraktor ciri untuk menghasilkan suatu representasi individual yang ekspresif dalam bentuk template, yang dapat disimpan dalam database di sistem biometrik atau dapat direkam pada berbagai media seperti kartu magnetik, chip, atau media penyimpan lain sesuai maksud penggunaannya. Pada fase pengenalan, bagian tubuh individu dibaca oleh pembaca biometrik dan dikonversi dalam bentuk digital, untuk diproses sebagai template. Selanjutnya, template ini dicocokkan dengan identifikasi individu yang disim-pan dalam database, kartu magnetik, chip, atau media penyimpan lain.

\section{IDENTIFIKASI IRIS}

Identifikasi iris (iris recognition) adalah metode identifikasi biometrik yang menggunakan pengenalan pola matematis data video dari iris mata seseorang. Iris memiliki pola yang kompleks dan unik pada setiap orang, yang dapat dilihat dari jarak tertentu. Pengertian sebagian orang mengenai identifikasi iris sering tertukar dengan identifikasi retina, yaitu suatu metode identifikasi biometrik yang lain. Identifikasi retina menggunakan pengenalan pola pembuluh darah retina yang unik pada setiap orang. Penggunaan identifikasi retina harus dilakukan dengan hatihati, karena akurasinya dapat berkurang pada beberapa penyakit atau gangguan mata seperti katarak dan astigmatisma berat.

Identifikasi iris dimulai dengan melokalisasi batas luar dan dalam dari iris (pupil and limbus) pada data gambar sebuah mata. Selanjutnya, program algoritma mendeteksi dan melakukan eksklusi kelopak mata, bulu mata, dan refleksi spektrum cahaya. Data gambar mata yang sekarang hanya berisi data gambar iris dinormalisasi untuk mengompensasi dilatasi atau konstriksi pupil, kemudian dianalisis dengan mengambil data berupa informasi pola iris untuk dapat dibandigkan dengan pola pembanding. Pada algoritma Daugman, sebagian besar informasi amplitudo dihilangkan; hal ini dimaksudkan agar pola iris tidak dipengaruhi oleh perubahan pada pencahayaan atau kontras kamera.

Metode identifikasi iris umumnya mengambil data gambar iris pada panjang gelombang sinar yang terlihat oleh mata (visible wavelenght, VW) yaitu 400-700 $\mathrm{nm}$ atau menggunakan panjang gelombang 700-900 nm yang disebut near infrared (NIR). Mayoritas metode identifikasi iris menggunakan panjang gelombang NIR yang dapat menembus iris berwarna gelap.

Sebagian besar populasi manusia di dunia memiliki iris berwarna gelap, yang lebih sulit didata oleh gelombang sinar VW. Penggunaan NIR juga membantu mengurangi kontaminasi data pola iris, dengan menghalangi refleksi kornea yang mungkin terbaca pada penggunaan VW.

Pembacaan menggunakan panjang gelombang NIR memiliki kelemahan karena cara ini tidak dapat membedakan efek yang ditimbulkan oleh melanin. Melanin atau kromofor yang merupakan komponen utama pemberi warna iris, terutama terdiri atas dua makromolekul heterogen yaitu eumelanin yang berwarna coklat hitam dan feomelanin yang berwarna kuning kemerahan. Penggabungan pengambilan data gambar dengan panjang gelombang NIR dan VW akan meningkatkan ketelitian identifikasi iris.

Identifikasi atau verifikasi identitas seseorang dilakukan dengan mencocokkan pola iris yang diperoleh dengan data pola iris yang sebelumnya telah dimasukkan ke dalam database. Data yang diperoleh dianalisis dengan komputer menggunakan metode bayesian untuk meningkatkan 
akurasinya. Pengambilan data biometrik untuk kepentingan data pembanding pada kelompok masyarakat yang lebih luas akan meningkatkan fungsionalitas identifikasi iris.

\section{Kelebihan identifikasi iris}

Metode identifikasi iris dianggap merupakan salah satu metode identifikasi biometrik yang ideal karena iris adalah organ internal yang terproteksi oleh kornea. Berbeda dengan sidik jari yang akan sulit dicocokkan bila kulit jari mengalami kerusakan, iris umumnya stabil dan datar. Konfigurasi geometrik iris dikontrol oleh otot sfingter pupil dan dilator pupil. Sedikitnya otot yang mampu menimbulkan perubahan menyebabkan iris lebih stabil dibanding metode identifikasi biometrik lain seperti metode pengenalan wajah.

Sejak masa gestasi, iris telah memiliki pola yang unik; bisa dikatakan bahwa tidak ada pola iris yang sama pada manusia, bahkan pada kembar identik sekalipun. Keunikan ini juga membuat kemungkinan terjadinya salah identifikasi amat kecil bila menggunakan metode identifikasi iris.

Metode identifikasi iris mengambil data gambar iris dari jarak $10 \mathrm{~cm}$ hingga beberapa meter, tergantung ketelitian alat pengambil gambar. Cara ini mengurangi kontak dan penularan penyakit akibat penggunaan alat, atau terjadinya penolakan pada budaya tertentu akibat terjadinya kontak langsung atau jarak individu yang diperiksa amat dekat dengan pemeriksa. Walau beberapa prosedur operasi dapat merubah warna dan bentuk keseluruhan iris, namun pola halus pada iris tetap stabil hingga beberapa dekade.

\section{Kekurangan identifikasi iris}

Kebanyakan teknologi biometrik mengalami kesulitan membedakan apakah data biometrik yang diperolehnya berasal dari jaringan hidup. Identifikasi biometrik baru dianggap terpercaya bila dapat dibuktikan bahwa data yang diperoleh merupakan data yang berasal dari bagian tubuh yang hidup, dan bukan dari cetakan atau gambar yang sengaja dibuat.

Pada identifikasi iris kekurangan di atas dapat diatasi dengan melakukan analisis spektrum warna untuk membedakan apakah data berasal dari jaringan iris atau bahan lain. Beberapa alat dibuat dengan menggunakan penyaring berupa pergerakan bola mata untuk menghindarkan digunakannya gambar mata untuk menggantikan mata orang yang akan diidentifikasi.

Identifikasi iris dapat mengalami kesalahan atau menurun ketepatannya, khususnya pada keadaan sebagai berikut, yaitu: penggunaan kacamata yang memantulkan cahaya atau menghalangi pengambilan gambar bola mata; lensa kontak untuk kepentingan kosmetik atau yang berpola; dan penggunaan cadar atau penutup wajah yang menutupi daerah mata. Oleh karena itu, sebelum identifikasi iris penggunaan hal tersebut di atas harus dipastikan untuk dilepas sementara waktu.

Identifikasi iris saat subjek menggunakan alkohol pada penelitian awal dianggap tidak akurat karena terdeteksinya deformitas iris akibat dilatasi atau konstriksi pupil subjek. Identifikasi iris idealnya dilakukan setelah subjek tidak lagi dalam pengaruh alkohol.

\section{DAFTAR PUSTAKA}

1. Barret W. Detecting a contact lens during iris recognition. [Cited 2008 Aug 28]. Available from: http://www.engr.sjsu.edu/wbarrett/publi cations/Composite.pdf.

2. Gibson research corporation. How big is your haystack? [cited 2013 July 29]. Available from: https://www.grc.com/haystack.htm.

3. Jain A, Pankanti S, Bolle R. Biometrics. Personal identification in networked society. Massachusets: Kluwer Academic Publishers; 2002.

4. Mescher AL. Junqueira's Basic Histology Text \& Atlas (Twelfth Edition). New York: McGrawHill Medical; 2010.

5. Peraturan Presiden Nomor 126 Tahun 2012 tentang perubahan ketiga atas peraturan 
presiden nomor 26 tahun 2009 tentang penerapan KTP berbasis nomor induk kependudukan secara nasional. Lembaran Negara Republik Indonesia tahun 2012 nomor 293.

6. Ross MH, Pawlina W. Histology a Text and Atlas (Sixth Edition). Philadelphia: Wolters Kluwer Lippincott Williams \& Wilkins; 2011.

7. Sarwoko EA. Mekanisme Sistem Identifikasi Biometrik. Semarang:
Universitas Diponegoro; 2006.

8. Thornton J, Kumar V. A Bayesian approach to deformed pattern matching of iris images. Pattern analysis and machine intelegence. 2007;(29)4:596606.

9. Vatsa M, Singh R, Jain A. Iris recognition under alcohol influence: A preliminary study. New Delhi: $5^{\text {th }}$ IAPR International Conference on Biometrics, 29 $9^{\text {th }}$ March 2012. 